\title{
Partial replacements of Stylosanthes scabra forage for lucerne in total mixed ration diet of Saanen goats
}

\author{
Thamsanqa Doctor Empire Mpanza ${ }^{1}$ and Abubeker Hassen ${ }^{1}$
}

\begin{abstract}
The inclusion of Stylosanthes scabra cv. Seca forage in the total mixed ration (TMR) as partial replacement of lucerne (alfalfa) was evaluated for its effects on voluntary feed intake, nutrient digestibility and nitrogen balance in Saanen goats. Three experimental diets were formulated having $0 \%$ Seca (T1), $15 \%$ Seca (T2) and $30 \%$ Seca (T3) as partial replacement of lucerne forage in the TMR diet for goats. Eighteen Saanen goats of about 7 months old were divided into three groups of six animals per group. Each group was randomly assigned to one of the three dietary treatments in a complete randomised design, and the study lasted for a period of 21 days. There was an increase in fibre and mineral content of the diets as Seca inclusion increased, but this resulted in the decrease of crude protein contents and in vitro organic matter digestibility. Animals that were fed $15 \%$ Seca recorded higher voluntary dry matter and nutrient (organic matter and fibres) intake, but the difference was not statistically significant $(P>0.05)$ as compared to the other treatments. Nutrient digestibility as well as nitrogen balance was not significantly different across the three diets. The lack of
\end{abstract}

Thamsanqa Doctor Empire Mpanza thamidempanza@webmail.co.za

Abubeker Hassen

Abubeker.Hassen@up.ac.za

Faculty of Natural and Agricultural Sciences, Department of Animal and Wildlife Sciences, University of Pretoria, Pretoria 0002, South Africa significant differences in feed intake, nutrient digestibility and nitrogen utilisation following the inclusion of Seca in the TMR suggests that S. scabra forage can partially replace lucerne in the TMR diet of goats.

Keywords In vitro fermentation $\cdot$ Feed intake $\cdot$ Lucerne Nitrogen balance $\cdot$ Seca

\section{Introduction}

Poor livestock production in the developing countries, particularly under smallholder farmers' condition, is attributed to over-dependence on low digestible, poor quality and inadequate feed supply from natural pastures. Sometimes, feed from natural pastures especially at maturity cannot even meet the maintenance requirements of the animals, and to address this situation, fodder trees, shrubs and herbaceous legumes have been used as supplementary feed for ruminants (Aregheore and Perera 2004; Hassen et al. 2006; Fadiyimu et al. 2010; Abegunde and Akinsoyinu 2011; Barakat et al. 2013). Forage legumes generally contain high protein, minerals and vitamins (Idowu et al. 2013); hence, they are often used as protein source to correct the protein deficiency of natural pastures (Tufarelli et al. 2010). Incorporating fodder legumes into ruminant diet as supplementary feed has been noted to improve feed efficiency and feed intake (Mendieta-Araica et al. 2009; Pen et al. 2013) and also improving animal performance in terms of milk production in Saanen goats (Baloyi et al. 2006) and Ankole cow (Mupenzi et al. 2009). Leguminous trees, shrubs and herbs can be easily grown by smallholder farmers, and their inclusion in animal's 
diet can reduce overall feeding cost (Ososanya et al. 2013).

Stylosanthes scabra cv. Seca is a hardy, erect shrubby legume which produces moderate to high biomass yield with relatively good nutritive value (Akinlade et al. 2008). The erect and shrubby nature of this legume along with the drought and frost tolerance characteristics makes the species suitable for sub-tropical dry areas (Chandra 2009). This legume has been evaluated for its adaptability and agronomic performance over a period of 3 years under rain-fed condition in sub-tropical climate of Pretoria, South Africa, and was found to be well adaptable and productive in sub-tropical climate of Pretoria (Mpanza et al. 2013). Furthermore, it was tested for acceptability, preferences and palatability with Saanen goats and was found acceptable and palatable (Mpanza et al. 2014). This shows the potential use of this species as alternative supplementary forage for livestock under smallholder farmers in South Africa. The inclusion of legume forages in the total mixed ration of animal as protein source helps to reduce the feed cost by replacing concentrate as protein source (Olafadehan et al. 2014). Seca forage contains above $17 \%$ crude protein with low level of tannins when grown in Pretoria, South Africa (Mpanza et al. 2014). Thus, it has the potential to replace lucerne in total mixed ration of goats as both forage and protein source. The objective of the present study was to investigate the effects of partial replacement of lucerne forage by S. scabra on the voluntary feed intake, digestibility and nitrogen balance of Saanen goats fed total mixed ration.

\section{Materials and methods}

\section{Study site}

The experiment was carried out at the small stock unit, Hatfield experimental Farm of the University of Pretoria, which is located at $25^{\circ} 44^{\prime} 30^{\prime \prime} \mathrm{S}, 28^{\circ} 15^{\prime} 30^{\prime \prime} \mathrm{E}$, at the elevation of $1370 \mathrm{~m}$ above sea level. The study area has two distinctive seasons: a dry season (March-September) and rainy season (October-February) with warm and humid condition in summer, while winter is dry, cold and sunny. Mean annual summer rainfall of this area is $674 \mathrm{~mm}$ (Hassen 2006).

\section{Forage material and treatments}

Sufficient quantities of $S$. scabra forage were harvested from screening trial plots that had been established for 3 years at the Hatfield Experimental Farm of the University of Pretoria. S. scabra accessions were harvested at about $100 \%$ flowering stage of growth in order to get maximum biomass production. The harvested forage was shade dried over a week, but due to small quantities of forage from each accessions, hence, they were mixed together in order to have enough forage material for the study. Other feed ingredients were purchased from the local market. Dried S. scabra, lucerne forages and Eragrostis curvula hay were chopped using hammer mill with $25-\mathrm{mm}$ diameter sieve and were thoroughly mixed with the concentrates to avoid feed selectivity.

S. scabra forage was used to partially replace lucerne forage in the traditional TMR diet referred to as orthodox diet. Thus, three dietary treatments were formulated where lucerne was replaced by 0,15 and $30 \%$ of $S$. scabra forage on dry matter bases (Table 1). A computer software developed by Langston University Goat Research and Extension programs (2000) was used to formulate the diets using the on-line link to the program. Each level of S. scabra inclusion was referred as treatment; thus, there were three dietary treatments (T1, T2 and T3, respectively). Each treatment was replicated using six Saanen male goats.

\section{Animals and their feeding}

A total of 18 healthy male Saanen goats of about 7 months old, with an average weight of $29.6 \pm 3.27 \mathrm{~kg}$, were used in the study for a period of 3 weeks. Goats were distributed in a complete randomised design with three dietary treatments and six replicates per treatment. The permit to use animals for the trial was granted by the Animal Use and Care Committee (AUCC) of the University of Pretoria (reference no. ec085-12). Animals were adapted to experimental diets for a period of 2 weeks. To reduce the period of stay in metabolic cages, the first week of adaptation was done in open pens, and second week was done in metabolic cages. This was followed by 7-day period of data collection where feed intake, feed refusal, total faecal and urine voided were collected, weighed and recorded, and representative samples taken for subsequent lab analysis.

\section{Data collection and chemical analysis}

Following 2 weeks of adaptation, data on feed intake, urine and total faecal output were collected for seven consecutive days. For voluntary feed intake estimation, feed offered and refusal were recorded daily per animal, and representative daily samples were taken. Faecal bags were used to collect daily faecal output per animal, and two samples were taken, one was used for daily dry mater output and the other one was stored in a freezer for later chemical analysis. Urine was collected in a plastic container, containing $20 \mathrm{ml}$ of $10 \%$ sulphuric acid $\left(\mathrm{H}_{2} \mathrm{SO}_{4}\right)$ to keep the $\mathrm{pH}$ below 4 in order to prevent the escape of ammonia. The volume of urine was measured daily, diluted with water to 51 (to prevent corrosiveness of ammonia), and thereafter, a sample of $100 \mathrm{ml}$ was taken and stored in a freezer for later nitrogen analysis. Daily samples that were taken from feed, faeces and urine were pooled at the end of 7 days 
of collection, and representative sub-samples were taken in duplicates per animals for chemical analysis.

Feed and faecal samples were then analysed in duplicates for dry matter (DM), ash, neutral detergent fibre (NDF), acid detergent fibre (ADF) and nitrogen concentration. Feed samples were also analysed for in vitro organic matter digestibility (IVOMD), calcium $(\mathrm{Ca})$ and phosphorus $(\mathrm{P})$ concentration. Proximate composition was analysed using standard procedure according to AOAC (2000), while fibre contents (neutral and acid detergent fibres) were determined according to Van Soest et al. (1991). In vitro digestible organic matter was determined following Tilley and Terry (1963) procedure as modified by Angels and Van Der Merwe (1967).

\section{Statistical analysis}

The data were analysed by the analysis of variance (ANOVA) using the general linear model (GLM) of Statistical Analysis Systems, Software version 9.0 (SAS 2002). The experimental diet and random error were included in the model. Where $F$ value has shown significant difference for the treatment effect, mean separation was undertaken using Duncan's multiple range test.

\section{Results}

The chemical composition of the experimental diets, lucerne and S. scabra forages is presented in Table 2. Lucerne hay which is traditionally used in TMR diet for goats is of medium quality with the crude protein (CP) content of about $17 \%$, and S. scabra forage used in this study had CP value slightly higher (18.56\%) than lucerne. There were no significant differences in the ADF and NDF contents of both lucerne and $S$. scabra forage. In the experimental diets formulated, crude protein content and in vitro organic matter digestibility (IVOMD) decrease slightly with increasing level of $S$. scabra forage inclusion, whereas ash, ADF, NDF and $\mathrm{Ca}$ increased with the increasing level of $S$. scabra forage inclusion on the TMR. However, the CP levels in the dietary treatments were above the critical level that supports the intake and normal functioning of a rumen. The difference in CP, IVOMD, ash, ADF and NDF was not significant $(P>0.05)$ across the treatments.

Voluntary dry matter intake of the experimental diets fed to the Saanen goats is presented in Table 3. Partial replacement of lucerne with $S$. scabra at 15 and $30 \%$ levels did not significantly $(P>0.05)$ affect the voluntary dry matter and nutrient intake of the Saanen goats. Animals fed $15 \%$ Seca seem to have a higher intake, while those on $30 \%$ Seca had the lowest, but the difference was not statistically significant. Partial replacement of lucerne by $S$. scabra had no significant effects $(P>0.05)$ on nutrient digestibility (Table 4). The dry matter, CP, ADF and OM digestibility seem to decrease with the increasing level of $S$. scabra forage inclusion though the difference was not statistically significant.

The daily nitrogen intake of the Saanen goats was not significantly affected by the replacement of lucerne with S. scabra forage in the TMR diet across all levels. However, the nitrogen intake seems to be the lowest for $30 \%$ Seca compared to the other two treatments (Table 5). Excretion of nitrogen through faeces was not significantly affected by treatment diet. However, animals fed $15 \%$ Seca diet had slightly higher nitrogen excretion in contrast with the other two treatments. Urinary nitrogen values seem to be slightly higher for animal fed on $30 \%$ TMR diet, though the difference was not statistically significant $(P>0.05)$ when compared with the other two treatments. Saanen goats fed dietary treatment with different levels (15 or $30 \%$ ) of $S$. scabra forage in TMR had a positive nitrogen balance. Although goats that were fed $30 \%$ Seca diet seem to have slightly lower nitrogen retention, the treatment was not statistically significant when compared with the other two treatments.

\section{Discussion}

The primary objective of this study was to assess the potential of using $S$. scabra forage as partial replacement of lucerne in total mixed ration formulated for Saanen goats. The nutrient profile of S. scabra shows that the forage has a good nutritive value that should result in good productive performance. The protein content of Seca forage used in the present study was above $11 \%$ which is adequate for growing beef cattle (Valarini and Possenti 2006) and was in the range that is required to support a lactating dairy cow (Poppi and McLennan 1995). However, when Seca was incorporated into TMR diet to partially replace lucerne, the $\mathrm{CP}$ content of the diets was slightly reduced. Similar pattern was observed for in vitro organic matter digestibility of the diets.

In the present study, the voluntary feed intake of dietary treatments was similar across the treatments, and this is in consistent with the findings of Schnaider et al. (2014). Nutrient intake for DM, OM, CP, NDF and ADF was similar in all dietary treatment groups; consequently, the in vivo digestibility of the nutrients was similar. The declining trends in digestibility of DM, OM and CP could be related to the observed relative increase in $\mathrm{ADF}$ and NDF content in the diet as the level of $S$. scabra forage inclusion increases. However, these results also agree with the report of Shi et al. (2014) and Sath et al. (2012). Even though 
NDF content seems to be slightly higher, the level was still below the upper limit of $60 \%$, capable of reducing dry matter intake (Meissner et al. 1991). Besides the level of NDF and ADF, Mahgoub et al. (2005) reported that the increasing level of non-conventional feed ingredients leads to the reduction of apparent nutrient digestibility.

Intake of CP slightly decreases as S. scabra level increases, and this could be attributed to the fact that even in dietary treatments, CP contents were reduced as the inclusion level of $S$. scabra forage increased. On the other hand, the excretion of nitrogen tends to increase in faecal and urine with the increasing level of S. scabra forage in diets, and this could be attributed to the probability that nitrogen intake exceeded the requirement of goats in all treatments. Previous study indicated that S. scabra forage contains a relatively low level of tannins (ranged from 0.87 to $1.64 \mathrm{~g} / \mathrm{kg}$ DM) (Mpanza et al. 2014). Although in this study, tannin content was not determined, one can expect an increase in tannin intake with increasing level of $S$. scabra forage inclusion in the TMR diet. This could partly explain the trend that is observed in nitrogen balance. However, dietary treatment had no significant effect on some of the measured response including intake, digestibility and nitrogen retention.

\section{Conclusions}

The inclusion of $S$. scabra forage in the TMR diet as partial replacement of lucerne did not show any significant effect in terms of dry matter and nutrient intake, digestibility and nitrogen utilisation. This means that up to $30 \%$ of lucerne can be partly replaced with S. scabra forage without compromising the nutritive value of the TMR diet of Saanen goats. However, this study evaluated only up to $30 \%$ inclusion level, and thus, future studies need to assess the possibility of replacing higher proportion of lucerne with Seca forage. However, the benefits need to be quantified also in terms of animal productive performance and cost benefit.

Acknowledgments We are grateful to Gauteng Department of Agriculture and Rural Development (GDARD) and National Research Foundation (NRF) for the financial support provided for this study. The first author is very grateful to the National Department of Agriculture, Forest and Fisheries (DAFF) for the financial support in the form of a stipend during the course of the study.

Conflict of interest We the authors of this work declare that we had no conflict of interest regarding this research work.
Informed consent The consent to use the animals was granted by the Animal Use and Care Committee (AUCC) of the University of Pretoria (reference no. ec085-12).

\section{Appendix}

Table 1 Ingredient of the total mixed ration for the experimental treatments

\begin{tabular}{|c|c|c|c|}
\hline \multirow[t]{2}{*}{ Ingredient ( $\%$ of total diet) } & \multicolumn{3}{|c|}{ Dietary treatments } \\
\hline & $\mathrm{T} 1$ & $\mathrm{~T} 2$ & $\mathrm{~T} 3$ \\
\hline Eragrostis hay & 20.0 & 20.0 & 20.0 \\
\hline Lucerne hay & 20.0 & 17.0 & 14.0 \\
\hline Stylosanthes scabra hay & - & 3.0 & 6.0 \\
\hline Salt & 0.5 & 0.5 & 0.5 \\
\hline Sodium bicarbonate & 0.4 & 0.4 & 0.4 \\
\hline Limestone, calcium carbonate & 1.2 & 1.2 & 1.2 \\
\hline Full fat soya roast & 1.2 & 1.2 & 1.2 \\
\hline Molasses meal & 2.0 & 2.0 & 2.0 \\
\hline Cotton seed & 4.0 & 4.0 & 4.0 \\
\hline Wheat bran & 5.0 & 5.0 & 5.0 \\
\hline Sunflower oil cake & 7.0 & 7.0 & 7.0 \\
\hline Hominy chop SA & 18.0 & 18.0 & 18.0 \\
\hline Maize ground & 21.0 & 21.0 & 21.0 \\
\hline Vitamin premix $^{\mathrm{a}}$ & 0.4 & 0.4 & 0.4 \\
\hline
\end{tabular}

$\mathrm{T} 1=0 \%$ Seca, $\mathrm{T} 2=15 \%$ Seca and $\mathrm{T} 3=30 \%$ Seca of lucerne hay in TMR diet

${ }^{\mathrm{a}}(18,000 \mathrm{iu} / \mathrm{lb} \mathrm{A}, 3920 \mathrm{iu} / \mathrm{lb} \mathrm{D}, 2.45 \mathrm{iu} / \mathrm{lb} \mathrm{E})$

Table 2 Chemical composition of treatments and legume forages

\begin{tabular}{lrrrrrr}
\hline \multirow{2}{*}{ Composition (\%DM) } & \multicolumn{3}{c}{ Dietary treatments } & & \multicolumn{2}{l}{ Legume forages } \\
\cline { 2 - 3 } & \multicolumn{1}{c}{$\mathrm{T} 1$} & $\mathrm{~T} 2$ & $\mathrm{~T} 3$ & & Lucerne hay & \multicolumn{2}{c}{ Seca ${ }^{\mathrm{a}}$ hay } \\
\hline $\mathrm{CP}$ & 13.7 & 13.4 & 13.6 & & 17.0 & 18.6 \\
$\mathrm{Ash}$ & 7.2 & 7.4 & 8.4 & 9.5 & 8.7 \\
$\mathrm{ADF}$ & 28.2 & 28.4 & 29.0 & 32.8 & 32.0 \\
$\mathrm{NDF}$ & 41.7 & 42.4 & 44.4 & 41.6 & 44.8 \\
$\mathrm{IVOMD}$ & 70.8 & 69.8 & 69.0 & - & - \\
$\mathrm{Ca}$ & 0.7 & 0.8 & 0.8 & - & - \\
$\mathrm{P}$ & 0.4 & 0.4 & 0.4 & - & - \\
\hline
\end{tabular}

${ }^{\text {a }}$ Stylosanthes scabra

$\mathrm{T} 1=0 \%$ Seca, $\mathrm{T} 2=15 \%$ Seca and $\mathrm{T} 3=30 \%$ Seca of lucerne hay in TMR diet

$C P$ crude protein, $A D F$ acid detergent fibre, $N D F$ neutral detergent fibre, IVOMD in vitro organic matter digestibility, $\mathrm{Ca}$ calcium, $P$ phosphorus 
Table 3 Body weight, dry matter and nutrients intake of Saanen goats fed TMR containing with or without Stylosanthes scabra forages

\begin{tabular}{|c|c|c|c|c|c|}
\hline \multirow[t]{2}{*}{ Parameters } & \multicolumn{3}{|c|}{ Dietary treatments } & \multirow[t]{2}{*}{ SEM } & \multirow[t]{2}{*}{$P$ value } \\
\hline & $\mathrm{T} 1$ & $\mathrm{~T} 2$ & $\mathrm{~T} 3$ & & \\
\hline Number of animal & 6 & 6 & 6 & & \\
\hline Initial body weight ( $\mathrm{kg} / \mathrm{head})$ & 31 & 29 & 29 & 1.4 & \\
\hline Final body weight (kg/head) & 34.4 & 33.7 & 33.1 & 1.26 & \\
\hline Feed intake (g/head/day) & 1372 & 1402 & 1330 & 27.8 & 0.1830 \\
\hline Feed intake (g/kg W $\mathrm{W}^{0.75} /$ day $)$ & 94.7 & 103.1 & 97.4 & 5.93 & 0.6057 \\
\hline \multicolumn{6}{|l|}{ Nutrients intake (g/head/day) } \\
\hline Organic matter intake & 1273 & 1300 & 1218 & 59.2 & 0.6213 \\
\hline Crude protein intake & 188.6 & 187.4 & 180.6 & 8.18 & 0.7586 \\
\hline NDF intake & 570.5 & 594.1 & 590.5 & 28.34 & 0.8200 \\
\hline ADF intake & 386.0 & 397.7 & 386.0 & 19.38 & 0.8862 \\
\hline
\end{tabular}

$\mathrm{T} 1=0 \%$ Seca, $\mathrm{T} 2=15 \%$ Seca and $\mathrm{T} 3=30 \%$ Seca of lucerne hay in TMR diet

SEM standard error of the mean, $N D F$ neutral detergent fibre, $A D F$ acid detergent fibre

Table 4 Effects of partial replacement of lucerne with Stylosanthes scabra on nutrients digestibility of Saanen goats

\begin{tabular}{llllll}
\hline Digestibility (\%) & \multicolumn{2}{l}{ Dietary treatments } & SEM & $P$ value \\
\cline { 2 - 4 } & T1 & T2 & T3 & & \\
\hline $\mathrm{DM}$ & 66.9 & 64.9 & 63.0 & 1.07 & 0.3435 \\
$\mathrm{OM}$ & 70.0 & 68.3 & 67.9 & 1.45 & 0.5671 \\
$\mathrm{CP}$ & 66.1 & 65.0 & 65.4 & 1.55 & 0.8894 \\
$\mathrm{NDF}$ & 50.4 & 49.5 & 51.9 & 2.26 & 0.7374 \\
$\mathrm{ADF}$ & 46.0 & 45.5 & 44.6 & 2.47 & 0.9264 \\
\hline
\end{tabular}

$\mathrm{T} 1=0 \%$ Seca, $\mathrm{T} 2=15 \%$ Seca and $\mathrm{T} 3=30 \%$ Seca of lucerne hay in TMR diet

$S E M$ standard error of the mean, $D M$ dry matter, $O M$ organic matter, $C P$ crude protein, $N D F$ neutral detergent fibre, $A D F$ acid detergent fibre

Table 5 Effects of partial replacement of lucerne with Stylosanthes scabra on nitrogen retention in Saanen goats

\begin{tabular}{lllllll}
\hline Parameter (g/head/day) & \multicolumn{3}{c}{ Dietary treatments } & \multirow{2}{*}{ SEM } & $P$ value \\
\cline { 2 - 4 } & T1 & T2 & T3 & & \\
\hline Number of animal & 6 & 6 & 6 & & \\
Total nitrogen intake & 30.2 & 30.0 & 29.0 & 1.31 & 0.7586 \\
Total nitrogen excreted in faeces & 10.3 & 10.6 & 10.1 & 0.80 & 0.9001 \\
Total nitrogen excreted in urine & 5.4 & 5.4 & 5.7 & 0.64 & 0.9595 \\
Total nitrogen excreted & 15.7 & 16.0 & 15.7 & 1.20 & 0.9771 \\
Total nitrogen retained & 14.5 & 14.0 & 13.2 & 0.89 & 0.5886
\end{tabular}

$\mathrm{T} 1=0 \%$ Seca, $\mathrm{T} 2=15 \%$ Seca and $\mathrm{T} 3=30 \%$ Seca of lucerne hay in TMR diet

SEM standard error of the means

\section{References}

Abegunde, T. O. and Akinsoyinu, A. O., 2011. Replacement effects of Panicum maximum with Ficus polita on performance of West African dwarf goats, Journal of Animal Physiology and Animal Nutrition, 95, 192-197

Akinlade, J.A., Farinu, G. O., Agboola, O. O., Akingbade, A. A., Ojebiyi, O. O. and Aderinola, O. A., 2008. Research note: Nutritive value of four accessions of Stylosanthes scabra in the derived savanna zone of Nigeria, Tropical Grasslands, 42,120-123

Angels, E. A. N. and Van Der Merwe, F. J., 1967. Application of an in vitro technique to South African forages with special reference to the effect of certain factora on the results, South African Journal of Agricultural Science, 10, 983-995

AOAC. 2000. Official methods of analysis (15th ed.). Association of Official Analytical Chemists. Washington, DC, USA

Aregheore, E. M. and Perera, D., 2004. Effect of supplementation of a basal diet of Maize Stover with Erythrina variegate, Gliricidia sepium or Leucaena leucocephala on feed intake and digestibility by goats, Tropical Animal Health and Production, 36, 175-189

Baloyi, J. J., Ngongoni, N. T., Hamudikuwanda, H., 2006. Milk production by Saanen does given forage and a tree browse legume as supplements to the conventional dairy concentrate and a basal diet of Katambora Rhodes (Chloris gayana) grass hay. South African Journal Education and Science Technology, 1(2), 58-64

Barakat, N.A., Laudadio, V., Cazzato, E. and Tufarelli, V., 2013. Potential contribution of Retama raetam (Forssk.) Webb \& Berthel as a forage shrub in Sinai, Egypt, Arid Land Research and Management, 27, $257-271$

Chandra, A., 2009. Diversity among Stylosanthes species: Habitat, edaphic and agro-climatic affinities leading to cultivar development, Journal of Environmental Biology, 30, 471-478

Fadiyimu, A. A., Alokan, J. A. and Fajemisin, A. N., 2010. Digestibility, nitrogen balance and haematological profile of West African dwarf sheep fed dietary levels of Moringa oleifera as supplement to Panicum maximum, Journal of American Science, 6, 634-643

Hassen, A., van Niekerk, W. A., Rethman, N. F. G. and Tjelele, T. J., 2006. Intake and in vivo digestibility of Indigofera forage compared wto Medicago sativa and Leucaena leucocephala by sheep, South African Journal of Animal Science, 36 (5), 67-70

Hassen A., 2006. Characterisation and evaluation of Indigofera species as potential forage and cover crops for semi-arid and arid ecosystems. $\mathrm{PhD}$ thesis. University of Pretoria, Pretoria, South Africa

Idowu, O. J., Arigbede, O. M., Dele, P. A., Olanite, J. A., Adelusi, O. O., Ojo, V. O. A. and Sunmola, A. S., 2013. Nutrients intake, performance and nitrogen balance of West African Dwarf sheep fed graded levels of toasted Enterolobium cyclocarpum seeds as supplementa to Panicum maximum, Pakistan Journal of Biological Sciences, 16, 1806-1810

Langston University Goat Research and Extension programs. 2000. Langston University Agricultural Research and Extension Programs. Langston.USA http://www.lresext.edu/goats/training/qa. htm1

Mahgoub, O., Kadim, I. T., Johnson, E. H., Srikandakumar, A., Alsaqri, N. M., Al-Abri, A. S. and Richie, A., 2005. The use of a concentrate containing meski (Prosopis juliflora) pods and date palm byproducts to replace commercial concentrate in diets of Omani sheep, Animal Feed Science and Technology. 120, 33-41

Meissner, H. H., Viljoen, M. O. and Van Niekerk, W.A., 1991. Intake and digestibility by sheep of Anthephora, Panicum, Rhodes and Smooth finger grass. In: Proceedings of the IV International Rangeland Congress, 22-26 April 1991, Montpellier, France. p. 648-649

Mendieta-Araica, B., E. Spörndly, Reyes-Sánchez, N., Norell, L. and Spörndly, R., 2009. Silage quality when Moringa oleifera is ensiled 
in mixtures with elephant grass, sugar cane and molasses, Grass and Forage Science, 64,364-373

Mpanza, T. D. E., Hassen, A., Donkin, E. F., Thantsha, M. S., 2013. The adaptability and yield performance of Stylosanthes scabra accessions in Pretoria, South Africa. Research Agenda Report 2012/2013. GDARD (Gauteng Department of Agri-culture and Rural Development), Johannesburg, South Africa

Mpanza, T. D. E., Hassen, A., Donkin, E. F. and Nzuza, W. T., 2014. Relative preference for, palatability and intake of Stylosanthes scabra accessions adapted in Pretoria, Tropical GrasslandsForrejes Tropicales, 2, 92-93

Mupenzi, M., E. Karenzi, Kanani, J. and Lussa Birasa, A., 2009. Use of supplement levels of Stylosanthes scabra (Stylo) leaf meal on milk yield of Ankole cows, Livestock Research for Rural Development. Volume 21, Article \#63. Retrieved July 5, 2011, from http://www. lrrd.org/lrrd21/5/muti21063.htm

Olafadehan, O. A., Adewumi, M. K. and Okunade, S. A., 2014. Effects of feeding tannin-containing forage in varying proportion with concentrate on the voluntary intake, haematological and biochemical indices of goats, Trakia Journal of Sciences, 12, 73-81

Ososanya, T. O., Odubola, O. T. and Shuaib-Rahim, A., 2013. Intake, nutrient digestibility and rumen ecology of West African dwarf sheep fed palm kernel oil and wheat offal supplemented diets, International Journal of AgriScience, 3, 380-386

Pen, M., Savage, D. B., Nolan, J. V. and Seng, M., 2013. Effect of Stylosanthes guianensis supplementation on intake and nitrogen metabolism of Bos indicus cattle offered a basal diet of mixed rice straw and tropical grass, Animal Production Science, 53, 453-457

Poppi, D. P. and McLennan, S. R., 1995. Protein and energy utilization by ruminants at pasture, Journal of Animal Science, 73, 278-290
SAS Institute Inc. 2002. SAS/STAT User's Guide: Version 9.0. SAS Institute Inc., Cary, North Carplina, USA

Sath, K., Sokun, K., Pauly, T. and Holtenius, K., 2012. Feed intake, digestibility, and $\mathrm{N}$ retention in cattle fed rice straw and para grass combined with different levels of protein derived from cassava foliage, Asian Australasian Journal of Animal Science, 25, 956-961

Schnaider, M.A., Rebeiro-Filho, H.M.N., Kozloski, G.V., Reiter, T., Orsoletta, A.C.D. and Dallabrida, A.L., 2014. Intake and Digestion of wethers fed with dwarf elephant grass hay with or without the inclusion of peanut hay, Tropical Animal Health and Production, 46, 975-980

Shi, F.H., Fang, L., Meng, Q. X., Wu, H., Du, J. P., Xie, X. X., Ren, L. P., Zhou, Z. M. and Zhou, B., 2014. Effects of partial or total replacement of maize with alternative feed source on digestibility, growth performance, blood metabolites and economic in Limousin crossbred cattle, Asian-Australasian Journal of Animal Science, 27, $1443-1451$

Tilley, J. M. A. and Terry, R. A., 1963. A two-stage technique for in vitro digestion of forage crops, Journal of British Grasslands Society, 8 , 104-111

Tufarelli, V., Cazzato, E., Ficco, A. and Laudadio, V., 2010. Evaluation of chemical composition and in vitro digestibility of appennine pasture plants using Yak (Bos grunniens) rumen fluid or faecal extract as inoculums source, Asian-Australian Journal of Animal Sciences, 23, $1587-1593$

Valarini, M. J. and Possenti, R. A., 2006. Research note: Nutritive value of a range of tropical forage legumes, Tropical Grasslands, 40, 183 187

Van Soest, P. J., Robertson, J. B. and Lewis, B. A., 1991. Methods for dietary fibre, neutral detergent fibre and non-starch polysaccharides in relation to animal nutrition, Dairy Science, 74, 3587-3597 